place until the cause and nuture of the mental aberration can be ascertained. Until recently no serious difficulty in dealing with such cases has arisen, since they have been received into the workhouse on a doctor's note, and there dealt with as the occasion demanded. Latterly, however, the authorities of Mill Road Infirmary have declined to receive them, owing, it is stated, to there being no accommodation in the workhouse for the alleged lunatics; and there has been no alternative but to take them back to the bridewell, where there is no proper provision for attending to them, and to bring them before the presiding magistrate the following day. As these persons are not charged with any offence for which they can be committed to goal, there is no alternative but to discharge them.

It is hiph time that reception houses for all cases of supposed insanity were established in the great centres of population. The Baronv Parish of Glasgow has set apart observation wards in the ordinary poorhouse to meet this difficulty, and we understand that good results have been obtained there, not only for the individuals, but also for the ratepayers.

\title{
LABORATORY OF THE SCOTTISH ASYLUMS.
}

The first annual report deals with a period of seven weeks. Four assistant medical officers had received a course of instruction, and reports had been made on material from six cases. The superintendent has entered on his duties with great zeal and ability, and has visited four asylums for the purpose of advising, besides aiding in research. The work in hand has been very varied, and Dr. Robertson is at present engaged in the study of the changes affecting the nerve cells in insanity. He states that the premises are well suited for the purpose. No doubt his report for next year will bear evidence of much good work accomplished in the same spirit as he has begun.

THE CASE OF REV. H. J. DOISWELL.

It is reported that the Home Secretary has decided not to interfere in this case. A petition was lately presented for Mr. Dodswell's release, on the grounds that the maximum punishment for the offence of which he was convicted had long since expired, and that if he was still considered insane he should now be detuined in a private, not a criminal asylum. We heartily approve of the Home Secretary's decision.

\section{FRAGILITY OF BONES IN THE INSANE.}

A patient in the Cork Asylum lately died, after it was found that several of his ribs had been fractured. Dr. Oscar Woods caused an expert examination of the bones to be made, with the result that they were proved to be excessively degenerated and fragile. It would seem that such observations should put an end to the loose statements occasionally made in a contrary sense.

THE RISKS OF ASYLUM LIFE.

Dr. J. A. Campbell lately addressed a letter to the Lancet, in which he showed how many hardships are endured by those engaged in the treatment of bodily and mental disease. He traced the life-history of a medical man through his training to practice, and alluded to the risk of infection at post-mortem examinations or in fever wards. He specially drew attention to the services rendered by army surgeons and their inadequate recognition, and stated that he had asked for particulars as to injuries, \&c., from forty-five English asylums in 1897. Dr. Campbell found that several medical officers had been seriously attacked. Lately two have had to retire owing to the results of injuries inflicted by patients. He referred to the murder of Coininissioner Lutwidge, the narrow escape of Dr. Wiglesworth, and the injury to Dr. Merson. We congratulate Dr. Campbell 